\title{
Therapeutic Approach in the Treatment of Medication-Related Osteonecrosis of the Jaw: Case Series of 3 Patients and State of the Art on Surgical Strategies
}

\author{
Erica Vettori ${ }^{1}$, Giulia Pipinato ${ }^{1}$, Rossana Bussani ${ }^{2}$, Fulvia Costantinides ${ }^{1}$, Vanessa Nicolin ${ }^{1}$, Lorenzo \\ Bevilacqua $^{1}$, Michele Maglione ${ }^{1}$ \\ ${ }^{1}$ Maxillofacial and Dental Surgical Unit, Department of Medical, Surgical and Health Sciences, University of Trieste, Trieste, \\ Italy. \\ ${ }^{2}$ Pathological Anatomy and Histopathology Unit, Department of Medical, Surgical and Health Sciences, University of Trieste, \\ Trieste, Italy.
}

\author{
Corresponding Author: \\ Erica Vettori \\ Maxillofacial and Dental Surgical Clinic \\ Department of Medical, Surgical and Health Sciences \\ University of Trieste \\ Piazza dell'Ospitale 1, 34129, Trieste \\ Italy \\ Phone: +390403992020 \\ Fax: +390403992022 \\ E-mail: evettori@units.it
}

\begin{abstract}
Background: Bisphosphonates and receptor activator of nuclear factor kappa-B ligand inhibitors are currently the most widely used antiresorptive therapies in bone metabolism diseases treatment. Unfortunately they can evoke medication-related osteonecrosis of the jaws. The present case series study proposes to evaluate clinical features, evolution and the surgical therapeutic approaches in three patients affected by medication-related osteonecrosis of the jaw and to review the state of art regarding the management of this complication in light of the most recent literature.

Methods: Three cases of medication-related osteonecrosis of the jaws are discussed, two related to bisphosphonates therapy (ibandronic acid) and one due to denosumab.

Results: All three patients were aged female and had probably a dental trigger agent. The lesions located in posterior mandible were treated in one case with the surgical approach alone and, in the other case, with surgical approach associated with Er:YAG laser. The lesion related to denosumab was treated with surgical approach and platelet rich fibrin application. A complete healing was always achieved.

Conclusions: Dentists should be aware of the potential risk of developing medication-related osteonecrosis of the jaws for patients who take or had taken antiresorptive drugs. The side effects of denosumab and bisphosphonates are partly overlapping and currently there is still no consensus about the therapeutic surgical options. Prevention and early detection of the lesions should be the primary strategy.
\end{abstract}

Keywords: antiresorptive drugs; laser therapy; oral surgery; osteonecrosis; platelet-rich fibrin.

\footnotetext{
Accepted for publication: 8 May 2021

To cite this article:

Vettori E, Pipinato G, Bussani R, Costantinides F, Nicolin V, Bevilacqua L, Maglione M.

Therapeutic Approach in the Treatment of Medication-Related Osteonecrosis of the Jaw: Case Series of 3 Patients and State of the Art on Surgical Strategies

J Oral Maxillofac Res 2021;12(2):e6

URL: http://www.ejomr.org/JOMR/archives/2021/2/e6/v12n2e6.pdf

doi: $10.5037 /$ jomr.2021.12206
} 


\section{INTRODUCTION}

Osteonecrosis of the jaws (ONJ) is a severe bone disease related to various medicaments: antiresorptive drugs (including bisphosphonates and receptor activator of nuclear factor kappa-B ligand [RANKL] inhibitors) and antiangiogenic drugs [1]].

Osteoclasts activity is depressed by antiresorptive agents, therefore, bone resorption is inhibited. Among these agents bisphosphonates, denosumab and selective estrogen modulators are the most used, rather than hormone replacement therapy and calcictonin which are mostly abandoned [2]. Typical and frequent indications for the use of these drugs are postmenopausal osteoporosis, bone malignant lesions secondary to breast or prostate cancer, and multiple myeloma [ 3 ].

Bisphosphonates, classified as being non-nitrogenous (etidronate, tiludronate and clodronate) or nitrogencontaining (pamidronate, alendronate, risendronate, zolendronate, ibandronate and neridronate) [1, $\underline{4}$, are currently the most widely used antiresorptive therapies for malignant and nonmalignant diseases characterized by various kinds of bone loss $[\underline{3}, \underline{5}]$. Oral administration of bisphosphonates is generally used to treat osteometabolic disease such as osteoporosis, osteopenia or more rare syndromes such as Paget's disease and osteogenesis imperfecta. Intravenous administrations is used for cancer-related conditions such as breast, prostate or lung cancer metastases and for the management of multiple myeloma [1].

Since 2003, Marx [6] report of bone necrosis induced by bisphosphonate-related osteonecrosis of the jaw (BRONJ) has generated great concern regarding the side effects of these drugs. Nitrogencontaining bisphosphonates are the only kind of bisphosphonates associated with osteonecrosis [1]. BRONJ is characterized by exposed necrotic bone in the maxillofacial region for more than 8 weeks in bisphosphonate users with no history of head and neck radiotherapy [4]. In the early stages of BRONJ there are often no symptoms and radiographic features may not be present, advanced stages, instead, are characterized by pain, paraesthesia, mucosal ulceration and exposed necrotic bone.

In 2006, a classification based on the clinical presentation of the disease has been proposed by American Association of Oral and Maxillofacial Surgeons (AAOMS) [7]. This classification defines three stages of BRONJ:

- Stage I, asymptomatic necrotic bone exposure;

- Stage II, bone necrosis with exposure, pain and infection;
- Stage III, bone necrosis with exposure, pain, infection and pathological fractures, or cutaneous fistulas.

The site of major prevalence of BRONJ has been reported to be the mandible although the maxilla can also be involved and both maxillary bones can be affected $[4, \underline{8}]$.

Because of the side effects related to the use of bisphosphonates, other therapeutic strategies for osteoporosis and bone metastasis or particular bone pathologies (such as Paget's disease) have been developed. The discovery of RANKL, that induces osteoclast differentiation, have led to the development of denosumab, a fully human monoclonal antibody that can bind and inhibit RANKL [ $[\underline{9}, \underline{9}]$. Like bisphosphonates, denosumab has been associated with ONJ [10]. In spite of bisphosphonates, whose side effects persist for years depending on the cumulative dose, the effects of RANK ligand inhibitors diminish rapidly after the end of administration [1].

Although ONJ related to non-antiresorptive anticancer agents is rare, its incidence is increasing (from $0.8 \%$ to $12 \%$ ) [7]. Antiangiogenetic agents do not block tumour cell growth, but interfere with new blood vessels formation.

In substance there are two types of drug related to ONJ: one that inhibits the angiogenetic growth factor or its receptor (bevacizumab, a monoclonal antibody), and the other one is a molecule which binds the tyrosine kinase receptor (sunitinib and sorafenib) [1]].

ONJ related to non-antiresorptive agents has a better prognosis in terms of percentage of healing and healing time compared to antiresorptive drugs, even though histology, radiology and management is similar [11].

Medication-related osteonecrosis of the jaw (MRONJ) has been defined as exposed necrotic bone in the oral cavity that does not heal within 8 weeks in patients who had taken antiresorptive (e.g. bisphosphonates and denosumab) or antiangiogenetic (bevacizumab) drugs [12].

For the treatment of MRONJ different conservative therapeutic approaches have been established, reserving surgery to cases of necessity in light of a risk-benefit ratio. In 2014 the AAOMS [13] published an update on the position paper regarding the staging and relative treatment of MRONJ (Table 1). Treatment approaches for MRONJ are still controversial; the lack of consensus has led to the development of new therapeutic strategies such as the use of platelet-rich fibrin (PRF) and laser therapy [12].

This study proposes to evaluate clinical features, evolution and surgical therapeutic approaches in three cases of medication-related osteonecrosis of 
Table 1. American Association of Oral and Maxillofacial Surgeons MRONJ position paper 2014 update [13]

\begin{tabular}{c|l|l}
\hline \multicolumn{1}{c|}{ MRONJ staging } & \multicolumn{1}{c}{ Treatment Strategies } \\
category & $\begin{array}{l}\text { No apparent necrotic bone in patients who have been treated with either oral } \\
\text { or intravenous (IV) bisphosphonates. }\end{array}$ & $\begin{array}{l}\text { - No treatment indicated. } \\
\text { - Patient education. }\end{array}$ \\
\hline Stage 0 & $\begin{array}{l}\text { No clinical evidence of necrotic bone, but non-specific clinical findings, } \\
\text { radiographic changes and symptoms. }\end{array}$ & $\begin{array}{l}\text { Systemic management, including the use of } \\
\text { pain medication and antibiotics. }\end{array}$ \\
\hline Stage 1 & $\begin{array}{l}\text { Exposed and necrotic bone, or fistulae that probes to bone, in patients who } \\
\text { are asymptomatic and have no evidence of infection. }\end{array}$ & $\begin{array}{l}\text { - Antibacterial mouth rinse. } \\
\text { - Clinical follow-up on a quarterly bias. } \\
\text { - Patient education and review of indications } \\
\text { for continued bisphosphonate therapy. }\end{array}$ \\
\hline Stage 2 & $\begin{array}{l}\text { Exposed and necrotic bone, or fistulae that probes to bone, associated with } \\
\text { infection as evidenced by pain and erythema in the region of the exposed } \\
\text { bone with or without purulent drainage. }\end{array}$ & $\begin{array}{l}\text { - Symptomatic treatment with oral antibiot- } \\
\text { ics. } \\
\text { - Oral antibacterial mouth rinse. } \\
\text { - Pain control. } \\
\text { - Debridement to relieve soft tissue irritation } \\
\text { and infection control. }\end{array}$ \\
\hline $\begin{array}{l}\text { Exposed and necrotic bone or a fistula that probes to bone in patients with } \\
\text { pain, infection, and one or more of the following: exposed and necrotic bone } \\
\text { extending beyond the region of alveolar bone, (i.e., inferior border and ramus } \\
\text { in the mandible, maxillary sinus and zygoma in the maxilla) resulting in } \\
\text { pathologic fracture, extra-oral fistula, oral antral/oral nasal communication, } \\
\text { or osteolysis extending to the inferior border of the mandible of sinus floor. }\end{array}$ & $\begin{array}{l}\text { - Antibacterial mouth rinse. } \\
\text { - Surgical debridement/resection for longer } \\
\text { term palliation of infection and pain. }\end{array}$ \\
\hline
\end{tabular}

MRONJ = medication-related osteonecrosis of the jaw.

the jaw and to review the state of art regarding the management of medication-related osteonecrosis of the jaw in light of the most recent literature.

\section{CASE DESCRIPTION AND RESULTS}

Three different cases of MRONJ were diagnosed and treated at the Maxillofacial and Dental Surgical Unit (Department of Medical, Surgical and Health Sciences, University of Trieste) between June 2014 and December 2016.

An informed written consent was obtained from each patient to use data for the research that was conducted in agreement with the guidelines of the Helsinki Declaration as revised in 1975 and amended in October 2003.

For each case pain assessment has been made with Numeric Rating Scale (NRS) which is an unidimensional measure of pain intensity whereby the patients rates the pain from 0 (no pain) to 10 (worst possible pain) [14].

\section{Case 1}

A 77-years old woman was admitted at the Dental Emergency Unit because of an unresolved perimplantitis in the site of left mandibular second premolar, with local pain (reported as 6 in NRS), gingiva swelling, dysesthesia of the left side of the lower lip and purulent discharge. The infection signs persisted despite of a long antibiotic therapy (about one month) and the dental implant removal done one month before.

The medical history showed hypertension, gastritis, hypercholesterolemia and osteoporosis.

The patient had taken alendronate - Fosamax ${ }^{\circledR}$ (Merck Sharp \& Dohme B.V.; Haarlem, The Netherlands) from 2010 until 2015 following by a therapy with ibandronic acid - Bonviva ${ }^{\circledR}$ (F. Hoffmann-La Roche Ltd.; Basel, Switzerland).

An orthopantomography (OPG) and a computed tomography (CT) were executed and revealed an osteolytic lesion with a bone sequestrum around the left mandibular second premolar site.

Clinical and radiographic features are shown in Figure 1.

Antibiotic therapy with amoxicillin and clavulanic acid 875 mg/125 mg - Neoduplamox ${ }^{\circledR}$ (GlaxoSmithKline; London, United Kingdom) Ter In Die (TID) and chlorhexidine mouthwashes (Curasept S.p.A.; Varese, Italy) were prescribed. Surgical intervention was performed under local anaesthesia (mepivacaine chlorohydrate with epinephrine 1: 100000 - Molteni Dental S.r.1.; Firenze, Italy), the left mandibular first premolar and the implant in the site of left mandibular first molar were extracted. Sequestrectomy and debridement of the necrotic tissue were executed until a bleeding bone was observed. Interrupted sutures with silk were applied.

The biopsy of the necrotic bone was performed. Histologic examination revealed the presence oral mucosa with massive reacutized chronic phlogosis and micro-abscessual areas (Figure 2). Diagnosis of MRONJ at Stage 2 was made. Antibiotic therapy was continued for one week after surgery. 


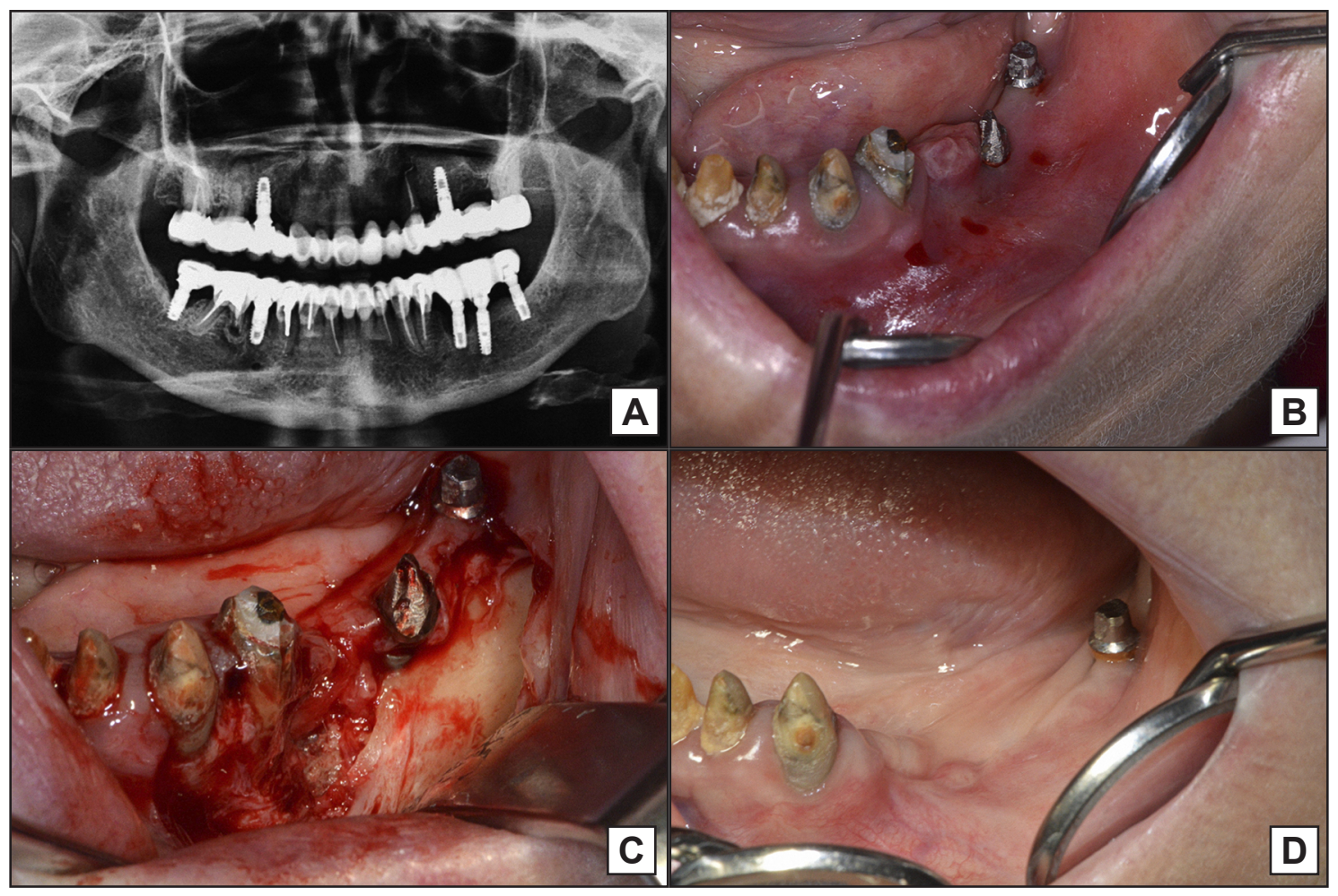

Figure 1. Case 1. $\mathrm{A}$ = orthopantomography before surgery; $\mathrm{B}=$ preoperative clinical features; $\mathrm{C}=$ surgical debridement; $\mathrm{D}=8$-months follow-up.

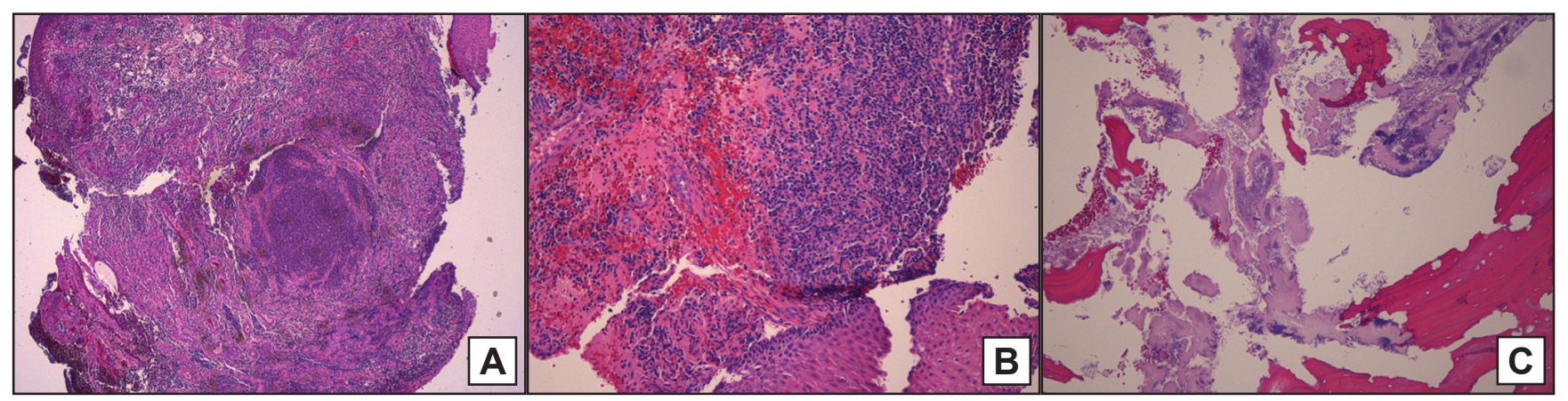

Figure 2. Case 1. Oral mucosa with massive reacutized chronic phlogosis and micro-abscessual areas. Hematoxylin and eosin stain: $\mathrm{A}=$ original magnification $\mathrm{x} 2.5 ; \mathrm{B}=$ original magnification $\mathrm{x} 10 ; \mathrm{C}=$ original magnification $\mathrm{x} 10$.

All along follow-up's span, presence of paraesthesia was evaluated asking the patient about sensibility of tongue, lip and chin; tests like 2-point discrimination, light touch and pinprick have been performed [15]. After three weeks, the debrided region was covered by normal mucosa. Dysesthesia of the left side of the lower lip improved.

After 8 months, a new CT was performed revealing a radiolucent area with well-defined borders and without surrounding periosteal reaction. There were no infections signs. Paraesthesia at the lower lip was the same as the one before the surgical debridement, but pain has regressed.

\section{Case 2}

A 66-years old woman was admitted at the Emergency
Unit of the Dental School because of pain, bad breath and exposed necrotic bone in the anterior lower jaw (Figure 3). Three months before the woman underwent inferior tooth extraction, she had eight teeth extracted in the inferior incisal and right molar region by her dentist.

The review of the patient's medical history revealed that for 21 months she had received monoclonal antibody therapy with denosumab - Prolia ${ }^{\circledR}$ (Amgen; Singapore) because of bone metastases from breast cancer diagnosed two years before.

The OPG showed a wide osteolytic area without defined borders in the anterior lower jaw (Figure 3). $\mathrm{CT}$ was requested to plan the surgery.

Antibiotic therapy with amoxicillin and clavulanic acid $875 \mathrm{mg} / 125 \mathrm{mg}$ - Neoduplamox ${ }^{\circledR}$ TID and chlorhexidine mouthwashes were prescribed. 


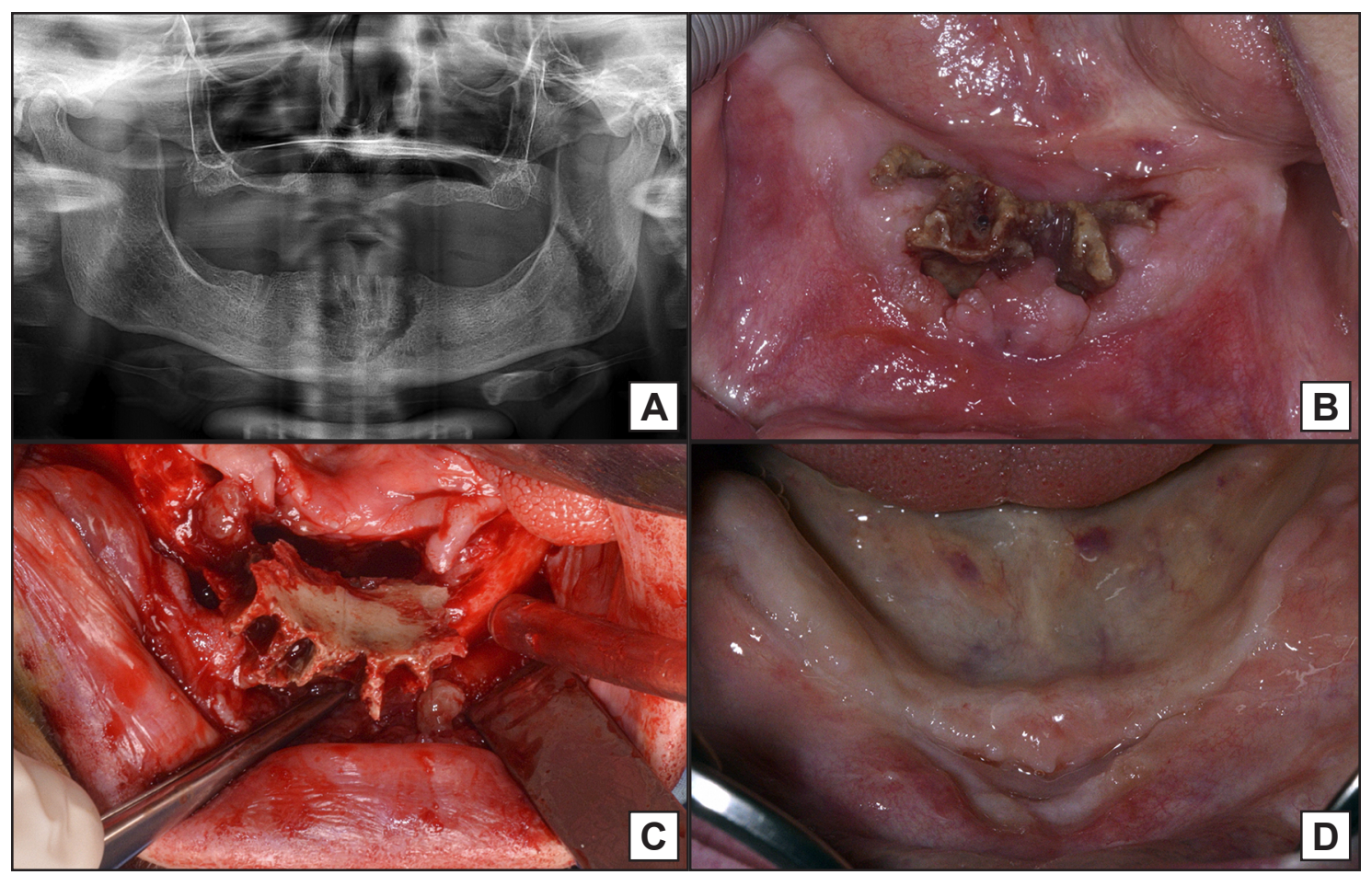

Figure 3. Case 2. $\mathrm{A}=$ Orthopantomography before surgery; $\mathrm{B}=$ preoperative clinical features; $\mathrm{C}=$ surgical debridement; $\mathrm{D}=12$-months follow-up.

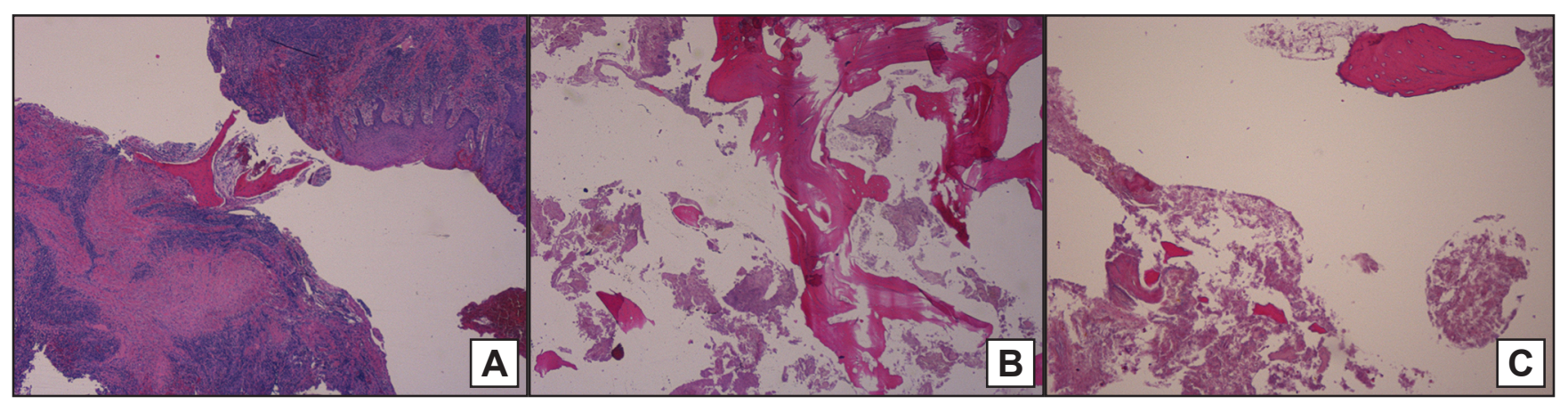

Figure 4. Case 2. Necrotized and regressed bone tissue with intense reacutized chronic phlogosis Hematoxylin and eosin stain: $\mathrm{A}=$ original magnification $\mathrm{x} 2.5 ; \mathrm{B}=$ original magnification $\mathrm{x} 2.5 ; \mathrm{C}=$ original magnification $\mathrm{x} 10$.

Surgical resection of bone necrosis was performed in operating room under local anaesthesia (mepivacaine chlorohydrate - Molteni Dental S.r.l.). Patient underwent bone surgical toilette and debridement until a bleeding bone was observed. The biopsy of necrotic bone were performed. Two swabs of macroscopically health bone were executed. PRF was used on the remaining bone in order to provide growth factors and improve wound healing and bone regeneration. Absorbable interrupted sutures with Vicryl ${ }^{\circledR}$ (Henry Schein Inc.; Melville, New York, USA) were placed. Antibiotic therapy was continued for 1 week after surgery.

Histologic examination revealed the presence of necrotic bone with chronic inflammatory cell infiltrate and muscle-connective tissue with stromal lymphoplasmacellular infiltrates and hemorrhagic imbibition (Figure 4). Stage 2 MRONJ diagnosis was made.

After 2 weeks a wound dehiscence was observed and a new CT (performed after 5 weeks from the first one) revealed a well-defined area of surgical resection with clear areas where bone bleeding was obtained.

After 7 weeks the debrided region was covered by normal mucosa.

OPG performed after about one year from the surgery revealed a good bone healing. The surgical wound was definitively healed, even if the patient has always reported discomfort with NRS $=3$ in the operated area.

\section{Case 3}

A 80-years old woman was admitted at the Dental Emergency Unit because of a paraesthesia of the left lower lip and pain reported as 5 in NRS scale. In her medical history it was reported she was suffering 
by hypertension, hypothyroidism, diabetes type II and osteoporosis.

Symptoms appeared after dental extractions approximately 3 years before.

An accurate review of her medical history was performed and it was emerged that she had started a therapy with Bonviva ${ }^{\circledR}$ - ibandronic acid $150 \mathrm{mg}$ once per month, 8 years before.

Clinical examination revealed abnormal posture of the left lower lip associated with low thermic and pain sensitivity. Mandibular profile was altered because of the presence of a non-mobile hard swelling without defined borders. Intraoral examination revealed the presence of a dental implant in 3.6 site with clinical evidence of purulent discharge and the presence of a vestibular soft mucosal swelling (Figure 5).

The OPG showed a large osteolytic lesion without defined borders; the bone inside this area had a cotton wool appearance (Figure 5).

Antibiotic therapy with amoxicillin and clavulanic acid $875 \mathrm{mg} / 125 \mathrm{mg}$ - Neoduplamox ${ }^{\circledR}$ TID was prescribed and a biopsy of the sick bone was performed. A head and neck CT was requested to plan the surgery.

Patient underwent bone surgical toilette under general and local anaesthesia (mepivacaine chlorohydrate Molteni Dental S.r.1.) and contextual removal of the implant with sequestrectomy and debridement until a bleeding bone was observed; the residual cavity was also treated with Er:YAG laser device (2940 nm, LightWalker AT - Fotona; Ljubljana, Slovenia).
Antibiotic therapy was continued for one week after surgery.

Histologic examination revealed the presence of necrotic bone with chronic inflammatory cell infiltrate, hyperplasia and parakeratosis of stratified squamous epithelium with underlying hyperplastic granulation tissue (Figure 6). Diagnosis of Stage 2 MRONJ was performed.

After three weeks the debrided region was covered by normal mucosa and a new CT (performed after 16 weeks from the first one) showed a radiolucent area with well-defined borders and without surrounding periosteal reaction. Hypoesthesia disappeared after surgery.

At one year follow-up no signs of relapse or recurrence appeared.

\section{DISCUSSION}

Thanks to their antiresorptive properties, bisphosphonates reduce morbidity and mortality in malignant and non-malignant bone diseases.

These drugs have an effect on increasing apoptosis and osteoclastic inhibition by binding the mineral component of bone: this action is well known even though their mechanism is not yet fully understood.

The way bisphosphonates work is that they disrupt the osteoblast-osteoclast interaction so they interfere with the mechanism of bone remodelling $[\underline{4}, \underline{6}, \underline{16}]$.

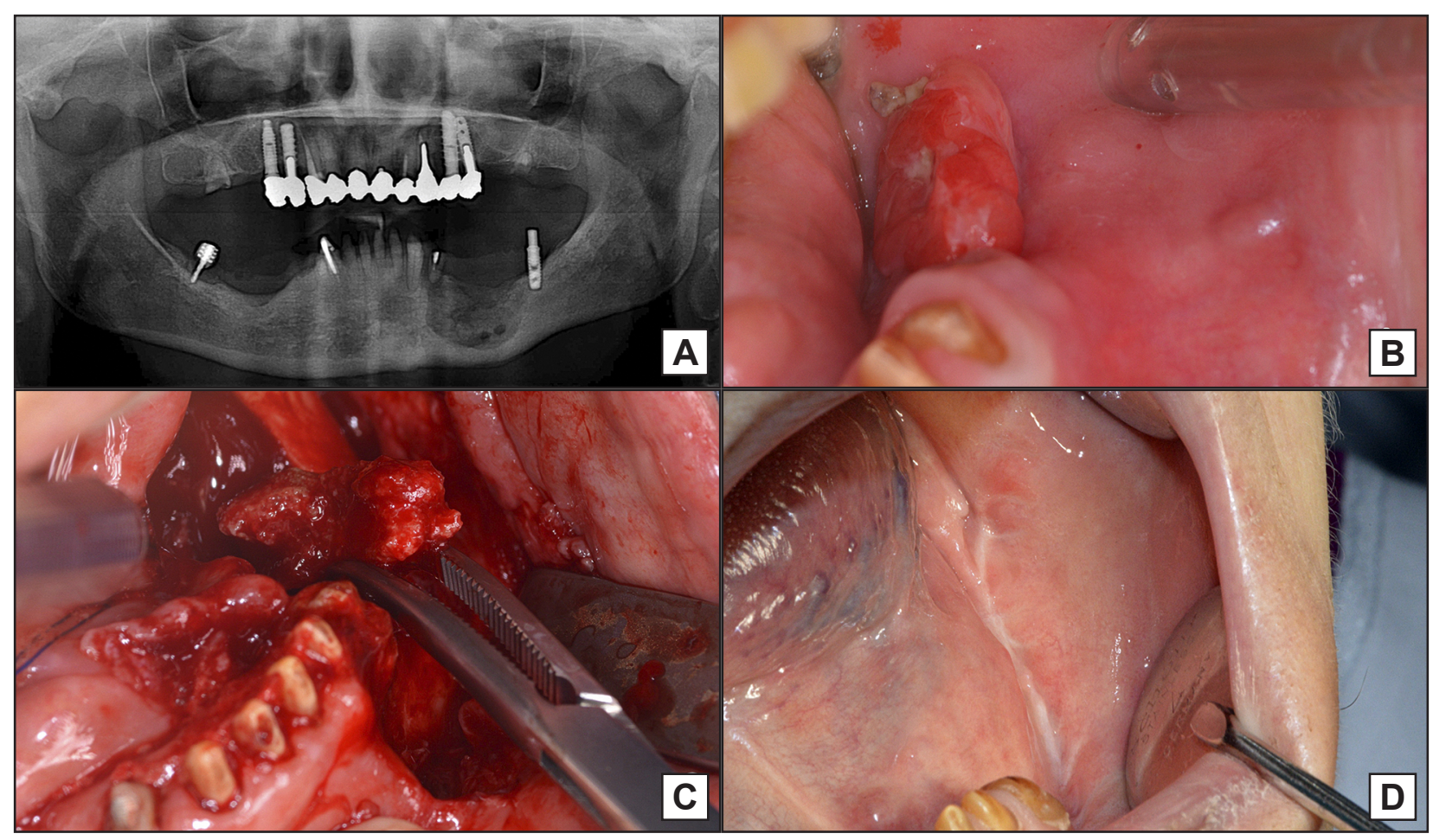

Figure 5. Case 3. $\mathrm{A}=$ Orthopantomography before surgery; $\mathrm{B}=$ preoperative clinical features; $\mathrm{C}=$ surgical debridement; $\mathrm{D}=18$-months follow-up. 


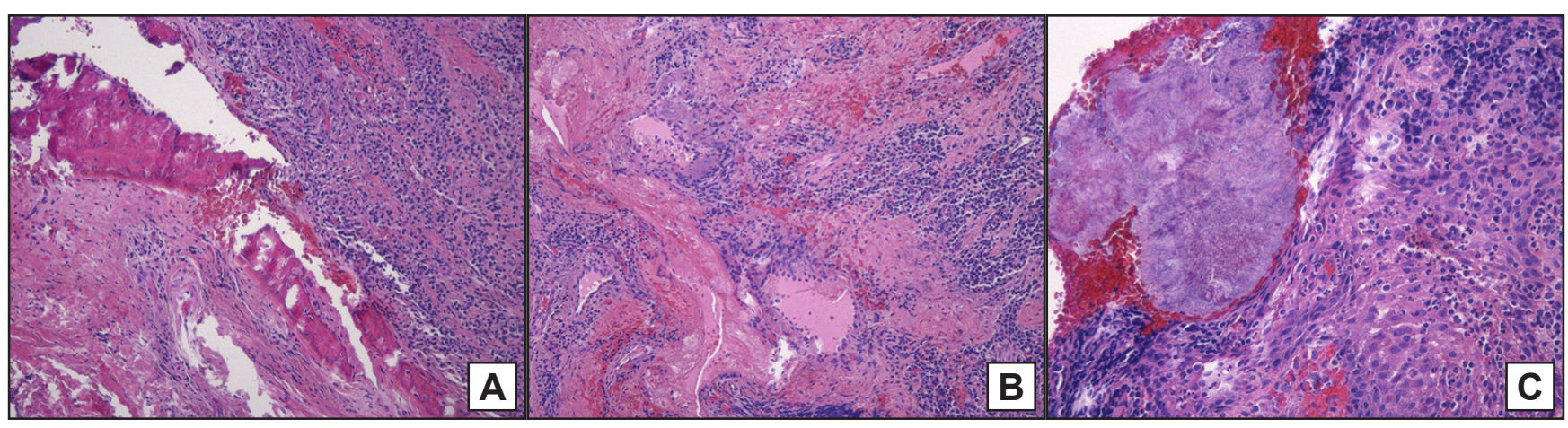

Figure 6. Case 3. Oral mucosa with intense phlogosis and aggregates of bacterial flora. Hematoxylin and eosin stain: A = original magnification $\mathrm{x} 1 ; \mathrm{B}=$ original magnification $\mathrm{x} 10 ; \mathrm{C}=$ original magnification $\mathrm{x} 20$.

Bisphosphonates can be administered orally, usually for the treatment of osteoporosis, or intravenously because of the higher power, generally in cases of bone metastases [4,7,17]. Like the bisphosphonates, denosumab has been associated with ONJ. Denosumab's pharmacodynamics and pharmacokinetics differ from that of bisphosphonates, for this reason, denosumab-related-ONJ may resolve more rapidly.

Denosumab is injected subcutaneously; the dosing ranges from $60 \mathrm{mg}$ every 6 months in postmenopausal women to $120 \mathrm{mg}$ every 4 weeks in the setting of malignant diseases. Instead of bisphosphonates, denosumab circulatory half-life is about 26 days, in fact its effect is reversible because it does not accumulate in the bone $[\underline{3}, \underline{4}, \underline{18}]$. Denosumab prevents the interaction of RANKL (a cytokine secreted by bone marrow stromal cells, osteoblasts and $\mathrm{T}$ cells, essential to induce osteoclast differentiation) with RANK (receptors present on osteoclasts and their precursor cells), blocking the formation, functional ability and survival of osteoclastic cells. The indications of denosumab are principally similar to bisphosphonates, that bind to the calcium hydroxyapatite present in bone and reduce bone resorption by affecting the function and survival of osteoclasts. However they do not affect the formation of osteoclasts $[9,19, \underline{20}]$.

The side effect profile of denosumab and bisphosphonates is partly overlapping: ONJ occur with similar frequency under treatment with denosumab and zoledronic acid, the most potent among bisphosphonates $[3,21,22]$. The greater prevalence of osteonecrosis in the maxillary bones can be explained by the major concentration of antiresorptive drugs in these structures, because of the continuous bone remodelling resulting from the constant functional trauma [4,23]. The site of the greater prevalence of ONJ has been reported to be the mandible; maybe, the antiangiogenetic properties of bisphosphonates has a relevant effect in mandible because of its physiologic characteristic of elevate blood supply and high turnover $[4,23]$.

Several risk factors can be related to the onset of the disease, including the nature of the drugs, its potency and absorption rate, local and systemic factors and the duration of administration. Osteonecrosis can develop spontaneously; however, dental surgery is considered to be the main triggering factor, followed by prosthetic trauma, periodontal disease, and dental implant placement $[\underline{4}, 24]$. Regarding the treatment of ONJ, reported therapeutic options include the use of antiseptic agents as $0.12 \%$ chlorhexidine, systemic antibiotics, and surgical debridement, either alone or combined with biological modulators such as plateletrich plasma, an high autologous platelet concentrated that provides a source of growth factors improving wound healing and bone regeneration [4].

Also PRF has proved to be useful after surgery, in fact PRF releases growth factors such as platet-derived growth factors, insulin-like growth factor and vascular endothelial growth factor which are important healing promoters [25].

Fernando de Almeida Barros Mourão et al. [26] in their study presented a series of patients treated with PRF applied after necrotic bone removal and showed a positive effect on promoting soft tissue healing and reducing post-operative pain.

Also Giudice et al. [27] in their paper found that the use of PRF to cover bone surface after surgical debridement of necrotic area brought to better shortterm results in terms of mucosal healing and quality of life. Although long-term evaluation showed no statistical differences between using or not PRF after surgery, with the cited study they demonstrated a significant improvement in short-term quality of life and a reduction of necessity of re-intervention.

Several studies [28-31] have described MRONJ surgical treatment performed with Er:YAG laser. Vescovi et al. [28] affirmed that a surgical approach performed with Er:YAG laser was associated with significantly better results when compared with traditional surgical treatment. 
Table 2. Personal and clinical characteristics of patients with MRONJ and treatment received $(n=3)$

\begin{tabular}{c|c|c|c|c|c|c|c|c|c|c}
\hline Case & Sex & Age & $\begin{array}{c}\text { Antiresorptive } \\
\text { agent }\end{array}$ & $\begin{array}{c}\text { Indication for } \\
\text { treatment }\end{array}$ & $\begin{array}{c}\text { Treatment } \\
\text { duration } \\
\text { (years) }\end{array}$ & $\begin{array}{c}\text { Lesion } \\
\text { site }\end{array}$ & $\begin{array}{c}\text { Stage } \\
\text { AAOM }\end{array}$ & $\begin{array}{c}\text { Triggering } \\
\text { factor }\end{array}$ & $\begin{array}{c}\text { Treatment for } \\
\text { MRONJ }\end{array}$ & Follow-up outcome \\
\hline 1 & $\mathrm{~F}$ & 77 & $\begin{array}{c}\text { Ibandronic acid } \\
\text { (alendronate) }\end{array}$ & Osteoporosis & $(5)+1$ & Mandible & 2 & $\begin{array}{c}\text { Implant } \\
\text { removal due to } \\
\text { perimplantitis }\end{array}$ & $\begin{array}{c}\text { Surgical } \\
\text { debridement }\end{array}$ & $\begin{array}{c}\text { Good wound } \\
\text { healing, paraesthesia } \\
\text { remained }\end{array}$ \\
\hline 2 & $\mathrm{~F}$ & 66 & Denosumab & $\begin{array}{c}\text { Bone } \\
\text { metastases } \\
\text { (breast cancer) }\end{array}$ & 1 & Mandible & 2 & $\begin{array}{c}\text { Dental } \\
\text { extraction }\end{array}$ & $\begin{array}{c}\text { Surgical } \\
\text { debridement } \\
+ \text { PRF }\end{array}$ & $\begin{array}{c}\text { Good wound healing, } \\
\text { remained discomfort } \\
\text { (NRS }=3)\end{array}$ \\
\hline 3 & $\mathrm{~F}$ & 80 & Ibandronic acid & Osteoporosis & 8 & Mandible & 2 & $\begin{array}{c}\text { Dental } \\
\text { extraction }\end{array}$ & $\begin{array}{c}\text { Surgical } \\
\text { debridement }+\end{array}$ & $\begin{array}{c}\text { Good wound healing, } \\
\text { Eno more paraesthesia }\end{array}$ \\
\hline
\end{tabular}

AAOM = American Association of Oral and Maxillofacial Surgeons; MRONJ = medication-related osteonecrosis of the jaw; $F=$ female; $\mathrm{PRF}=$ platelet-rich fibrin; $\mathrm{NRS}=$ numeric rating scale .

Er:YAG laser emits a wavelength of $2940 \mathrm{~nm}$ which is highly affine to water and hydroxyapatite; laser technology allows an efficient ablation of hard tissues without producing important thermal increasing which could determine necrotizing effects on tissues [29-31].

Laser works producing water vapour that expands increasing pressure until micro-explosions develop. The result is tissue removal and this process is called thermally-induced mechanical ablation [32].

The cold ablation produced by Er:YAG laser has been demonstrated to be effective and safe in removal of granulation tissue and root surface debridement. Furthermore it also promotes new bone formation in periodontal surgery also because of the lower increase of the temperature compared with rotary tools $[\underline{30}, \underline{31}, \underline{33}]$.

Discontinuing the drug after ONJ diagnosis is controversial: denosumab's related ONJ, due to its different mechanism of pathogenesis, may resolve more rapidly after a drug holiday compared to BRONJ [10]. Usually, when a drug use causes a serious side effect, the drug is interrupted but, as these medications are also used to inhibit bone metastases growing, benefits of their continuation is almost always overweigh their risks.

There is still no consensus about the treatment of the ONJ because the pathological mechanism of disease is not fully understood, but there is agreement on the importance of prevention for bisphosphonate users. In the present study, all the analysed cases have been diagnosed after symptoms developing; this is according to literature's findings that ONJ diagnosis is not easy during asymptomatic, reinforcing the importance of an accurate medical history and of prevention [34,35]. Clinical and radiographic evaluation of patient's dental status is required before starting therapy with antiresorptive drugs, in order to identify and remove possible sites of infections, such as teeth with periodontal disease, residual roots, chronic infections. At risk patients must have acceptable oral health when antiresorptive therapy begins, for the purpose of avoid the necessity of tooth extractions during (and after) the antiresorptive therapy [36].

In our experience all the three surgical options used gave us good results; all patients were Stage 2 MRONJ and have been treated with surgery associated with antibiotic therapy and antimicrobial rinses as indicated by the AAOMS position paper [13]. Moreover, in one case Er:YAG laser was also used and in another one PRF was applied. Due to our results all the three strategies have been revealed to be effective in MRONJ treatment. The three cases presented in this paper are summarized in Table 2.

\section{CONCLUSIONS}

Medication-related osteonecrosis of the jaw is a complication that can cause oncologic treatment interruptions and can deteriorate quality of life. It is necessary and very important for dentists to be aware of the potential risk of developing medication-related osteonecrosis of the jaw in patients who take or had taken in the past antiresorptive drugs. Prevention and a particular care toward these patients with periodic checks should be the primary strategies for antiresorptive drugs users. The use of platelet-rich fibrin and Erb:YAG laser seems promoting therapeutic options in the treatment of medication-related osteonecrosis of the jaw but more studies should be developed to establish a precise way to assess the medication-related osteonecrosis of the jaw risk and to define the more effective treatment strategies in light of a benefit-risk ratio. 


\section{ACKNOWLEDGMENT AND DISCLOSURE STATEMENTS}

The authors report no conflicts of interest related to this study. No external funding to declare.

\section{REFERENCES}

1. Tenore G, Palaia G, Gaimari G, Brugnoletti O, Bove L, Lo Giudice R, Mohsen M, Romeo U. MedicationRelated Osteonecrosis of the Jaws (MRONJ): Etiological update. Senses Sci. 2014 Dec;4(1):147-52. [doi: 10.14616/sands-2014-4-147152]

2. Novak S. Antiresorptivni lijekovi u lijecenju osteoporoze [Antiresorptive agents in the treatment of osteoporosis]. Reumatizam. 2014;61(2):89-94. Croatian. [Medline: 25427401]

3. Otto S. Medication-Related Osteonecrosis of the Jaws: Bisphosphonates, Denosumab, and New Agents. Berlin Heidelberg; Springer: 2015. [doi: 10.1007/978-3-662-43733-9]

4. Mathias Duarte LF, dos Reis HB, Tucci R, Dib LL. Bisphosphonate-related osteonecrosis of the jaws: analysis of a case series at a dental school. Spec Care Dentist. 2014 Mar-Apr;34(2):77-83. [Medline: 23875734] [doi: 10.1111/scd.12023]

5. Baron R, Ferrari S, Russell RG. Denosumab and bisphosphonates: different mechanisms of action and effects. Bone. 2011 Apr 1;48(4):677-92. [Medline: 21145999] [doi: 10.1016/j.bone.2010.11.020]

6. Marx RE. Pamidronate (Aredia) and zoledronate (Zometa) induced avascular necrosis of the jaws: a growing epidemic. J Oral Maxillofac Surg. 2003 Sep;61(9):1115-7. [Medline: 12966493] [doi: 10.1016/S0278-2391(03)00720-1]

7. Advisory Task Force on Bisphosphonate-Related Ostenonecrosis of the Jaws, American Association of Oral and Maxillofacial Surgeons. American Association of Oral and Maxillofacial Surgeons position paper on bisphosphonaterelated osteonecrosis of the jaws. J Oral Maxillofac Surg. 2007 Mar;65(3):369-76. [Medline: 17307580] [doi: 10.1016/j.joms.2006.11.003]

8. Ruggiero SL, Fantasia J, Carlson E. Bisphosphonate-related osteonecrosis of the jaw: background and guidelines for diagnosis, staging and management. Oral Surg Oral Med Oral Pathol Oral Radiol Endod. 2006 Oct;102(4):433-41. [Medline: 16997108] [doi: 10.1016/j.tripleo.2006.06.004]

9. Benjamin B, Benjamin MA, Swe M, Sugathan S. Review on the comparison of effectiveness between denosumab and bisphosphonates in post-menopausal osteoporosis. Osteoporos Sarcopenia. 2016 Jun;2(2):77-81. [Medline: $\underline{30775470]}$ [PMC free article: $\underline{6372735}$ ] [doi: 10.1016/j.afos.2016.03.003]

10. Malan J, Ettinger K, Naumann E, Beirne OR. The relationship of denosumab pharmacology and osteonecrosis of the jaws. Oral Surg Oral Med Oral Pathol Oral Radiol. 2012 Dec;114(6):671-6. [Medline: 23159111] [doi: 10.1016/i.00oo.2012.08.439]

11. Nicolatou-Galitis O, Kouri M, Papadopoulou E, Vardas E, Galiti D, Epstein JB, Elad S, Campisi G, Tsoukalas N, BektasKayhan K, Tan W, Body JJ, Migliorati C, Lalla RV; MASCC Bone Study Group. Osteonecrosis of the jaw related to nonantiresorptive medications: a systematic review. Support Care Cancer. 2019 Feb;27(2):383-394. [Medline: 30353228] [doi: 10.1007/s00520-018-4501-x]

12. Khan AA, Morrison A, Hanley DA, Felsenberg D, McCauley LK, O’Ryan F, Reid IR, Ruggiero SL, Taguchi A, Tetradis S, Watts NB, Brandi ML, Peters E, Guise T, Eastell R, Cheung AM, Morin SN, Masri B, Cooper C, Morgan SL, Obermayer-Pietsch B, Langdahl BL, Al Dabagh R, Davison KS, Kendler DL, Sándor GK, Josse RG, Bhandari M, El Rabbany M, Pierroz DD, Sulimani R, Saunders DP, Brown JP, Compston J; International Task Force on Osteonecrosis of the Jaw. Diagnosis and management of osteonecrosis of the jaw: a systematic review and international consensus. J Bone Miner Res. 2015 Jan;30(1):3-23. [Medline: 25414052] [doi: 10.1002/jbmr.2405]

13. Ruggiero SL, Dodson TB, Fantasia J, Goodday R, Aghaloo T, Mehrotra B, O'Ryan F; American Association of Oral and Maxillofacial Surgeons. American Association of Oral and Maxillofacial Surgeons position paper on medicationrelated osteonecrosis of the jaw--2014 update. J Oral Maxillofac Surg. 2014 Oct;72(10):1938-56. [Medline: 25234529] [doi: 10.1016/i.joms.2014.04.031]

14. Krebs EE, Carey TS, Weinberger M. Accuracy of the pain numeric rating scale as a screening test in primary care. J Gen Intern Med. 2007 Oct;22(10):1453-8. [Medline: 17668269] [PMC free article: 2305860] [doi: 10.1007/s11606-007-0321-2]

15. Fusaro F, Costantinides F, Maglione M, Dalessandri D, Vettori E, DI Lenarda R. Comparison of orthopantomography and CT accuracy in predicting inferior alveolar nerve injury following lower third molar surgical extraction. Minerva Stomatol. 2017 Oct;66(5):193-200. [Medline: 28880060] [doi: 10.23736/S0026-4970.17.04026-2]

16. Tubiana-Hulin M, Spielmann M, Roux C, Campone M, Zelek L, Gligorov J, Samson J, Lesclous P, Laredo JD, Namer M. Physiopathology and management of osteonecrosis of the jaws related to bisphosphonate therapy for malignant bone lesions. A French expert panel analysis. Crit Rev Oncol Hematol. 2009 Jul;71(1):12-21. [Medline: 19070505] [doi: 10.1016/j.critrevonc.2008.10.009] 
17. Diz P, Limeres J, Fedele S, Seoane J, Diniz M, Feijoo JF. Is oral bisphosphonate-related osteonecrosis of the jaw an endemic condition? Med Hypotheses. 2012 Feb;78(2):315-8. [Medline: 22136947] [doi: 10.1016/j.mehy.2011.11.011]

18. Yee AJ, Raje NS. Denosumab, a RANK ligand inhibitor, for the management of bone loss in cancer patients. Clin Interv Aging. 2012;7:331-8. [Medline: 22977302] [PMC free article: 3437759] [doi: 10.2147/CIA.S14566]

19. Russell RG, Watts NB, Ebetino FH, Rogers MJ. Mechanisms of action of bisphosphonates: similarities and differences and their potential influence on clinical efficacy. Osteoporos Int. 2008 Jun;19(6):733-59. [Medline: 18214569] [doi: $10.1007 / \mathrm{s} 00198-007-0540-8]$

20. Boyle WJ, Simonet WS, Lacey DL. Osteoclast differentiation and activation. Nature. 2003 May 15;423(6937):337-42. [Medline: 12748652] [doi: 10.1038/nature01658]

21. Henry DH, Costa L, Goldwasser F, Hirsh V, Hungria V, Prausova J, Scagliotti GV, Sleeboom H, Spencer A, Vadhan-Raj S, von Moos R, Willenbacher W, Woll PJ, Wang J, Jiang Q, Jun S, Dansey R, Yeh H. Randomized, double-blind study of denosumab versus zoledronic acid in the treatment of bone metastases in patients with advanced cancer (excluding breast and prostate cancer) or multiple myeloma. J Clin Oncol. 2011 Mar 20;29(9):1125-32. [Medline: 21343556] [doi: 10.1200/JCO.2010.31.3304]

22. Qi WX, Tang LN, He AN, Yao Y, Shen Z. Risk of osteonecrosis of the jaw in cancer patients receiving denosumab: a meta-analysis of seven randomized controlled trials. Int J Clin Oncol. 2014 Apr;19(2):403-10. [Medline: 23605142] [doi: 10.1007/s10147-013-0561-6]

23. Marx RE, Sawatari Y, Fortin M, Broumand V. Bisphosphonate-induced exposed bone (osteonecrosis/osteopetrosis) of the jaws: risk factors, recognition, prevention, and treatment. J Oral Maxillofac Surg. 2005 Nov;63(11):1567-75. [Medline: 16243172] [doi: 10.1016/j.joms.2005.07.010]

24. Assael LA. Oral bisphosphonates as a cause of bisphosphonate-related osteonecrosis of the jaws: clinical findings, assessment of risks, and preventive strategies. J Oral Maxillofac Surg. 2009 May;67(5 Suppl):35-43. [Medline: 19371813] [doi: 10.1016/j.joms.2009.01.003]

25. Su CY, Kuo YP, Tseng YH, Su CH, Burnouf T. In vitro release of growth factors from platelet-rich fibrin (PRF): a proposal to optimize the clinical applications of PRF. Oral Surg Oral Med Oral Pathol Oral Radiol Endod. 2009 Jul;108(1):56-61. [Medline: 19451002 ] [doi: 10.1016/j.tripleo.2009.02.004]

26. Fernando de Almeida Barros Mourão C, Calasans-Maia MD, Del Fabbro M, Le Drapper Vieira F, Coutinho de Mello Machado R, Capella R, Miron RJ, Gomes Alves G. The use of Platelet-rich Fibrin in the management of medication-related osteonecrosis of the jaw: A case series. J Stomatol Oral Maxillofac Surg. 2020 Feb;121(1):84-89. [Medline: $\underline{\text { 30794883] }}$ [doi: 10.1016/j.jormas.2019.02.011]

27. Giudice A, Barone S, Giudice C, Bennardo F, Fortunato L. Can platelet-rich fibrin improve healing after surgical treatment of medication-related osteonecrosis of the jaw? A pilot study. Oral Surg Oral Med Oral Pathol Oral Radiol. 2018 Nov;126(5):390-403. [Medline: 30108028] [doi: 10.1016/j.0000.2018.06.007]

28. Vescovi P, Giovannacci I, Otto S, Manfredi M, Merigo E, Fornaini C, Nammour S, Meleti M. Medication-Related Osteonecrosis of the Jaw: An Autofluorescence-Guided Surgical Approach Performed with Er:YAG Laser. Photomed Laser Surg. 2015 Aug;33(8):437-42. [Medline: 26226174] [doi: 10.1089/pho.2015.3927]

29. Merigo E, Cella L, Oppici A, Cristina Arbasi M, Clini F, Fontana M, Fornaini C. Combined Approach to Treat Medication-Related Osteonecrosis of the Jaws. J Lasers Med Sci. 2018 Spring;9(2):92-100. [Medline: 30026893] [PMC free article: 6046388] [doi: 10.15171/jlms.2018.19]

30. Curti M, Rocca JP, Bertrand MF, Nammour S. Morpho-structural aspects of Er:YAG-prepared class V cavities. J Clin Laser Med Surg. 2004 Apr;22(2):119-23. [Medline: 15165386] [doi: 10.1089/104454704774076172]

31. Angiero F, Sannino C, Borloni R, Crippa R, Benedicenti S, Romanos GE. Osteonecrosis of the jaws caused by bisphosphonates: evaluation of a new therapeutic approach using the Er:YAG laser. Lasers Med Sci. 2009 Nov;24(6): 849-56. [Medline: 19277823] [doi: 10.1007/s10103-009-0654-7]

32. Vescovi P, Manfredi M, Merigo E, Meleti M, Fornaini C, Rocca JP, Nammour S. Surgical approach with Er:YAG laser on osteonecrosis of the jaws (ONJ) in patients under bisphosphonate therapy (BPT). Lasers Med Sci. 2010 Jan;25(1):101-13. [Medline: 19543768] [doi: 10.1007/s10103-009-0687-y]

33. Mizutani K, Aoki A, Takasaki AA, Kinoshita A, Hayashi C, Oda S, Ishikawa I. Periodontal tissue healing following flap surgery using an Er:YAG laser in dogs. Lasers Surg Med. 2006 Apr;38(4):314-24. [Medline: 16568444] [doi: 10.1002/1sm.20299]

34. Martins MA, Martins MD, Lascala CA, Curi MM, Migliorati CA, Tenis CA, Marques MM. Association of laser phototherapy with PRP improves healing of bisphosphonate-related osteonecrosis of the jaws in cancer patients: a preliminary study. Oral Oncol. 2012 Jan;48(1):79-84. [Medline: 21940198] [doi: 10.1016/j.oraloncology.2011.08.010]

35. Diniz-Freitas M, López-Cedrún JL, Fernández-Sanromán J, García-García A, Fernández-Feijoo J, Diz-Dios P. Oral bisphosphonate-related osteonecrosis of the jaws: Clinical characteristics of a series of 20 cases in Spain. Med Oral Patol Oral Cir Bucal. 2012 Sep 1;17(5):e751-8. [Medline: 22549688] [PMC free article: 3482517] [doi: 10.4317/medoral.18041]

36. Hennedige AA, Jayasinghe J, Khajeh J, Macfarlane TV. Systematic review on the incidence of bisphosphonate related osteonecrosis of the jaw in children diagnosed with osteogenesis imperfecta. J Oral Maxillofac Res. 2014 Jan 1;4(4):e1. [Medline: 24478911] [PMC free article: 3904727] [doi: 10.5037/jomr.2013.4401] 


\section{To cite this article:}

Vettori E, Pipinato G, Bussani R, Costantinides F, Nicolin V, Bevilacqua L, Maglione M.

Therapeutic Approach in the Treatment of Medication-Related Osteonecrosis of the Jaw: Case Series of 3 Patients and State of the Art on Surgical Strategies

J Oral Maxillofac Res 2021;12(2):e6

URL: http://www.ejomr.org/JOMR/archives/2021/2/e6/v12n2e6.pdf

doi: $\underline{10.5037 / \text { jomr.2021.12206 }}$

Copyright (C) Vettori E, Pipinato G, Bussani R, Costantinides F, Nicolin V, Bevilacqua L, Maglione M. Published in the JOURNAL OF ORAL \& MAXILLOFACIAL RESEARCH (http://www.ejomr.org), 30 June 2021.

This is an open-access article, first published in the JOURNAL OF ORAL \& MAXILLOFACIAL RESEARCH, distributed under the terms of the Creative Commons Attribution-Noncommercial-No Derivative Works 3.0 Unported License, which permits unrestricted non-commercial use, distribution, and reproduction in any medium, provided the original work and is properly cited. The copyright, license information and link to the original publication on (http://www.ejomr.org) must be included. 